\title{
DETECTION OF ALKALOID, FLAVONOID, AND TERPENOID COMPOUNDS IN BREAD (Artocarpus communis Forst.) LEAVES AND PULPS
}

\author{
Handriani Kristanti ${ }^{1}$, Woro Anindito Sri Tunjung ${ }^{2}$ \\ Faculty of Biology, Universitas Gadjah Mada \\ JI. Teknika Selatan, Sekip Utara, Yogyakarta 55281 \\ E-mail : w_anindito@yahoo.co.nz
}

\begin{abstract}
Leaves of bread tree (Sukun/ Artocarpus communis Forst.) can be used to cure skin diseases, heart, kidneys, and inflamation. The advantageous of bread might be related with its secondary metabolite compounds. The purpose of this research was to detect and compare the content of alkaloid, flavonoid, and terpenoid compounds in bread leaves and pulps using Thin layer Chromatography (TLC) methods. The coloring reagents were dragendorf for alkaloid, sitroborat for flavanoid and sulfate vanillin for terpenoid. Reference compounds used for alkaloid is quinine, rutine for the flavonoid, and terpeniol for terpenoid. The result indicated that alkaloid were detected in chloroform extracts of leaves with Rf score 0.76 and methanol extracts with $\mathrm{Rf} 0.8$, while the alkaloid in pulps weren't detected. This showed that the leaves were contain of polar and nonpolar alkaloid. Flavonoid were detected in leaves with $\mathrm{Rf}$ value 0.89 and in pulps with $\mathrm{Rf}$ value 0.9 . This result indicated that flavonoid in the leaves and pulps possibly the same compound. Terpenoid were detected in the methanol and chloroform extract of leaves (4 spots) and pulps (2 spots). Moreover, there were spots which have the same $\mathrm{Rf}$ value in chloroform and methanol extracts of the leaves (Rf :0,625 and 0,99). In addition, the pulps extracts (chloroform and methanol) have the same Rf values with reference, that was 0,31 . It was proved that the pulps contain terpeniol. It can be concluded that alkaloid was only detected in leaves, while flavonoid and terpenoid present in leaves and pulps of bread tree.
\end{abstract}

Key words : Artocarpus communis Forst., alkaloid, flavonoid, terpenoid, TLC.

\section{INTRODUCTION}

Bread tree (Artocarpus communis Forst.) was tropical plants that have multiple functions: fruit can be used as food, wood can be used as home furnishings and building materials, flowers can be used as a toothache medicine, and leaves can be used as traditional medicine (Widowati, 2003). Leaves of bread can used to cure skin diseases, heart, kidneys, also function as anti-inflamation. The advantageous of bread might be related with its secondary metabolite compounds. The used of bread as traditional medicine was focused mainly to the leaves. Although bread's pulp are not used as medicine, they possibly have the similar secondary metabolite compounds as in leaves means pulp also have potency to be used as traditional medicine as well as leaves (channell,1998). A plant can function as a traditional medicine because of the content of secondary metabolites (Torssell, 1983). Secondary metabolites such as alkaloid, flavonoid and terpenoid had specific characteristics that varied chemical structure, its spread was relatively stable, biosynthesis was influenced by the amount and activity of enzymes and cell specialization in the process of differentiation and development of the organism (Mursyidi, 1990). Alkaloid was nitrogen organic bases compounds that derived from plants and animals. Alkaloid acted as a regulator of growth supplied nitrogen to plants and antimicrobial. Flavonoid was secondary metabolites with tetrasiklik siklopentanoperhidrofenantren structure. Flavonoid acted to protect plants from UV radiation, temperature stress, anticancer, antimicrobial and antiviral, tolerance to heavy 
metals, defense against from insects and chemical signals to attract insects. Terpenoid was secondary metabolites with isopien framework. Terpenoid acted as antiseptic, antimicrobial, antibiotics, plant growth regulators, cured skin disorders and diabetes (Lenny, 2006). Research on the content of alkaloid, flavonoid, and terpenoid compounds in fruits and leaves of bread tree was very limited. Therefore this study was conducted to determine difference of alkaloid, flavonoid, and terpenoid profile in the leaves and pulps of bread tree (Artocarpus communis Forst.).

\section{MATERIALS AND METHODS}

This research was conducted on February-April 2013 in the Integrated Research and Analysis Laboratorium (LPPT) Universitas Gadjah Mada, Yogyakarta.

\section{Sampling}

Samples of leaves and pulps were taken in Mergangsan Kidul Yogyakarta. Then, the samples were dried until they got constant dry weight and made simplicia powder.

\section{Detection of Alkaloid}

For the detection of alkaloid, the powder was preextracted using methanol $96 \%$ and $\mathrm{NH}_{3} 10 \%$ or $\mathrm{NH}_{3} 10 \%$ only, then extracted with $\mathrm{CHCl}_{3}$.

\section{Detection of Flavonoid}

The powder was hydrolyzed with $4 \mathrm{~N} \mathrm{HCl}$ for 30 minutes and then dissolved in ether. The solution will separate into two layers, then took the upper layer (ether phase).

\section{Detection of Terpenoid}

The powder was extracted using maceration method by dissolving powder into chloroform or methanol $96 \%$ which had been placed in the Erlenmeyer glass. Then, closed with plastic and gave erlenmeyer rubber. After that, shaked the solution with a magnetic stirrer and allowed to stand for $2 \times 24$ hours. Subsequently, the solution was filtered using filter paper and funnel. Then, filtrate inserted into the cup and evaporated in a water bath until get dried.

\section{Running}

Each extract was spotted on silica gel $\mathrm{F}_{254}$ plat. Then eluted with a mobile phase of methanol: ammonia $(100: 1,5)$ for alkaloid, ethyl acetate: formic acid: acetic acid: water (100:11:11:27) for flavonoid, and for terpenoid using the mobile phase was toluene: ethyl acetate (93:7). Reference compounds used for alkaloid were quinine, rutine for the flavonoid, and terpeniol for terpenoid

\section{Staining}

The chromatogram observed under UV $254 \mathrm{~nm}$ and $366 \mathrm{~nm}$ then sprayed with the coloring reagent dragendorf that produced orange color for alkaloid, sitroborat that produced yellow color for flavanoid and sulfate vanillin that produced purple color for terpenoid. Analysis of secon-dary metabolites compounds were done by measurement of $\mathrm{Rf}$ score. The formula of 
Rf score was distance of sample or reference compound divided to distance of the solvent.

\section{RESULTS AND DISCUSSION}

Spots of secondary metabolites in TLC plate can be seen in figure 1 (alkaloid), figure 2 (flavonoid), and figure 3 (terpenoid).

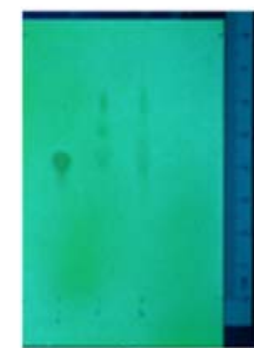

(a)

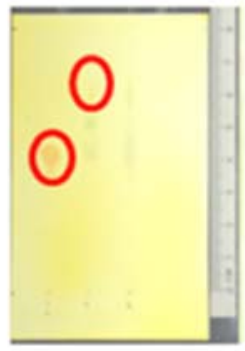

(c)

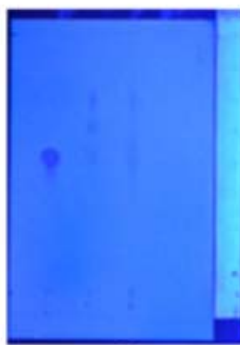

(b)

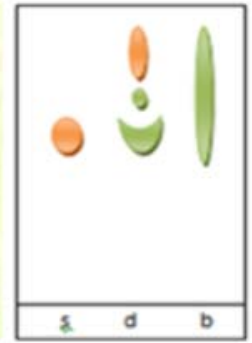

(d)

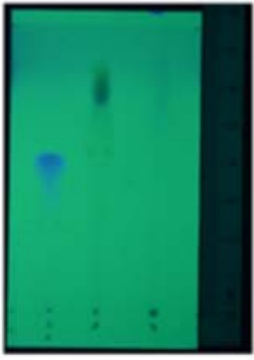

(a)

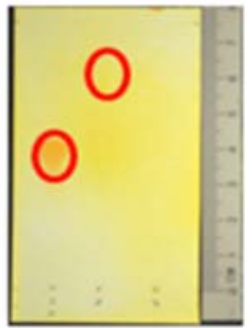

(c)

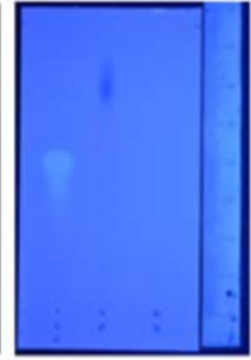

(b)

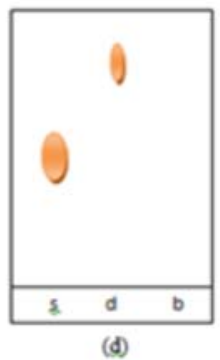

Figure 1. Detection of alkaloid compounds in chloroform extract (left) and methanol extract (right) with light treatment (a) UV $254 \mathrm{~nm}$, (b) UV $366 \mathrm{~nm}$, (c) visible; (d) monogram, after sprayed with reagent Dragendorf. Positions in TLC plate from left to right were reference compound, leave and pulp. Red circle were spot of alkaloid.

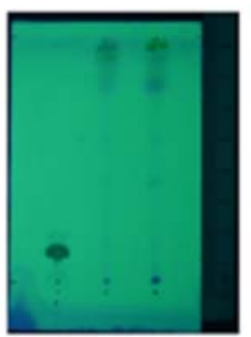

(a)

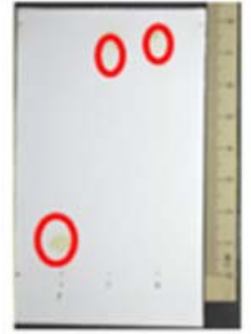

(c)

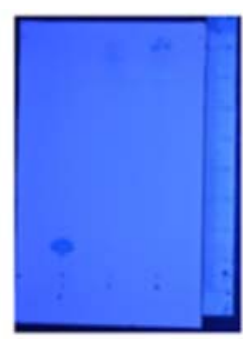

(b)

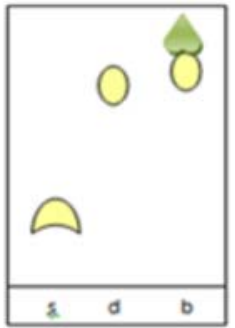

(d)

Figure 2. Detection of flavonoid compounds with light treatment (a) UV $254 \mathrm{~nm}$, (b) UV $366 \mathrm{~nm}$, (c) visible, (d) monogram, after sprayed with reagent Sitroborat

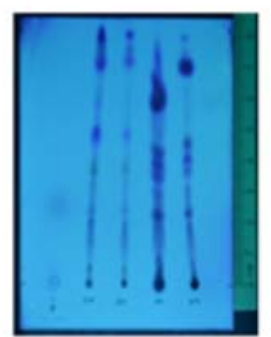

(a)

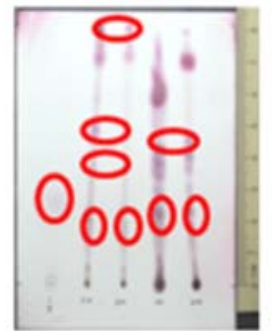

(c)

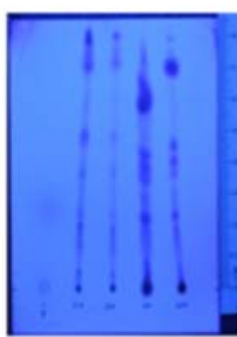

(b)

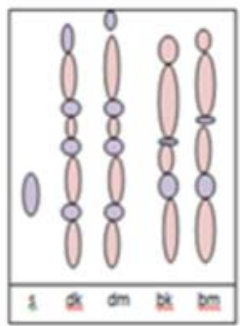

(d)
Figure 3. Detection of terpenoid compounds in chloroform and methanol extracts with light treatments (a) UV $254 \mathrm{~nm}$, (b) UV $366 \mathrm{~nm}$, (c) visible, (d) monogram, after sprayed with reagent sulfate vanillin 
In figure 2 and 3 , positions in TLC plate from left to right were reference compound, leave, and pulp. Red circle were spot of flavonoid (Figure 2) and terpenoid (Figure 3).

Result of the study indicated that alkaloid was detected in chloroform extracts of leaves with $\mathrm{Rf}$ score 0.76 and methanol extracts of leaves with $\mathrm{Rf} 0.8$, while the alkaloid was not detected in pulp. This showed that the leaves of bread tree were contain of polar and semipolar or nonpolar alkaloid. Flavonoid were detected in leaves with Rf values of 0.89 and in pulp with $\mathrm{Rf}$ value of 0.90 . This result indicated that flavonoid in the leaves possibly the same compound with pulps. Terpenoid were detected in the methanol extract and chloroform extract of leaves (produced 4 spots) and pulps (produced 2 spots). Moreover, there were spots which have the same $\mathrm{Rf}$ value in chloroform and methanol extracts of the leaves (Rf score were 0,625 and 0,99 ), indicated that terpenoid in the leaves possibly the same compound with pulps. In addition, the pulp of bread tree extracts (both chloroform and methanol) has the same Rf values with standards, that was 0,31 . It was proved that the pulp contains terpeniol. It can be concluded that alkaloid was only detected in leaves of bread tree, while flavonoid and terpenoid present in leaves and pulps of bread tree. Rf score can be seen in table 1.

Table 1. Rf score of alkaloid, flavonoid and terpenoid compounds in the leaves and pulps

\begin{tabular}{|c|c|c|c|c|c|}
\hline \multirow{3}{*}{$\begin{array}{l}\text { Secondary } \\
\text { Metabolite } \\
\text { compounds }\end{array}$} & \multicolumn{5}{|c|}{ Rf score } \\
\hline & \multirow{2}{*}{$\begin{array}{l}\text { Reference } \\
\text { compounds }\end{array}$} & \multicolumn{2}{|c|}{ Leaves of bread tree } & \multicolumn{2}{|c|}{ Pulps of bread tree } \\
\hline & & $\begin{array}{c}\text { Chloroform } \\
\text { extract }\end{array}$ & $\begin{array}{c}\text { Methanol } \\
\text { extract }\end{array}$ & $\begin{array}{c}\text { Chloroform } \\
\text { extract }\end{array}$ & $\begin{array}{c}\text { Methanol } \\
\text { extract }\end{array}$ \\
\hline \multirow[t]{2}{*}{ Alkaloid } & Quinine $=$ & 0,76 & 0,8 & ND & ND \\
\hline & 0,55 & & & & \\
\hline \multirow[t]{4}{*}{ Terpenoid } & Terpeniol = & 0,3 & 0,28 & 0,31 & 0,31 \\
\hline & 0,31 & 0,5 & 0,48 & 0,43 & 0,53 \\
\hline & & 0,63 & 0,63 & & \\
\hline & & 0,99 & 0,99 & & \\
\hline Flavonoid & Rutine $=0,14$ & \multicolumn{2}{|c|}{0,89} & \multicolumn{2}{|c|}{0,90} \\
\hline
\end{tabular}

Based on the table 1, it can be seen that the profile of the chromatogram between the leaves and pulps of bread tree have the similarity on Rf values and the amount of staining spot. Leaves and pulps contained similar kind of secondary metabolites. Because of this reason, both organs can substitute each other to be used as traditional medicine. Furthermore, both leaves and pulps are available throughout the year. Hence, we can use both of them to get advantageous of their secondary metabolite compounds.

\section{CONCLUSION}

Flavonoid and terpenoid were detected in leaves and pulps of bread tree. While, alkaloid only detected in leaves of bread tree. Based on their Rf score, it can be concluded that flavonoid and terpenoid compounds in leaves were similar with pulps.

\section{REFERENCES}

Channell, R.J.P. 1998. Natural Product Isolation. Humana Press Inc. New Jersey, pp : 354, 356. 
Lenny, S. 2006. Senyawa Flavonoida, Fenilpropanoida dan Alkaloida. Departemen Kimia FMIPA Universitas Sumatera Utara. Medan, hal : 14-18.

Mursyidi, A. 1990. Analisis Metabolit Sekunder. Pusat Antar Universitas UGM. Yogyakarta, hal : $1-4$.

Torssell, K.B.G. 1983. Natural product chemistry: Aistryof the genus Sideritis from the Canarylslands. Mechanistic and Biosynthetic Approach to Secondary Biochem. System. Ecol. 7,. Metabolism. John Wiley \& Son, Chichester, U. K. pp:115-120.

Widowati, S. 2003. Prospek Tepung Sukun Untuk Berbagai Produk Makanan Olahan Dalam Upaya Menunjang Diversivikasi Pangan. Program Pasca Sarjana. Institut Pertanian Bogor. Bogor, hal : 26. 